\title{
Effects of Maturity on Chemical Composition and Antioxidant Activity of Sacha Inchi (Plukenetia volubilis L.) Cultivated in NorthernThailand
}

\author{
Riantong SINGANUSONG ${ }^{1, *}$ and Sudarat JIAMYANGYUEN ${ }^{2}$ \\ ${ }^{1}$ Centre of Excellence in Fats and Oils, Faculty of Agriculture, Natural Resources and Environment, \\ Naresuan University, Phitsanulok 65000, Thailand \\ ${ }^{2}$ Department of Agro-Industry, Faculty of Agriculture, Natural Resources and Environment, \\ Naresuan University, Phitsanulok 65000, Thailand
}

("Corresponding author's e-mail: riantongs@nu.ac.th)

Received: 7 February 2018, Revised: 14 November 2018, Accepted: 7 December 2018

\begin{abstract}
Sacha inchi is cultivated commercially in Thailand for its edible kernels and oil. Highest quality sacha inchi is normally associated with highest oil content. Samples of 3 maturity stages: green, greenish brown, and brown and dry, were collected from 2 different harvests and comparisons were made based on composition and antioxidant analysis. In each harvest, all 3 stages were collected from the Phitsanulok and Chiang Rai provinces. There were 12 samples plus 2 controls. As maturity increased, moisture content of samples decreased, while oil content increased. Oil content ranged from $38.15-48.81 \mathrm{~g} / 100 \mathrm{~g}$. Protein content ranged from $16.23-18.98 \mathrm{~g} / 100 \mathrm{~g}$. Fibre content was $14.50-22.24 \mathrm{~g} / 100 \mathrm{~g}$, ash content was $2.70-3.06 \mathrm{~g} / 100 \mathrm{~g}$, and carbohydrate content was $7.70-19.47 \mathrm{~g} / 100 \mathrm{~g}$. The total phenolic content (TPC) was $103-385 \mathrm{mg} / 100 \mathrm{~g}$, and antioxidant activity was $9.36-13.72 \%$ for DPPH and 5,803.99 $10,700 \mathrm{mg}$ Trolox equivalent for FRAP. Average SFA, MUFA, and PUFA contents were 3.35, 4.63, and $30.91 \mathrm{~g} / 100 \mathrm{~g}$, respectively. Most common FA was omega-6 PUFA, followed by omega-3 and omega-9. Omega-6 to omega-3 ratio was 1.12 - 1.56. Samples with highest oil content were brown and dry samples harvested from Chiang Rai (47.26 g/100 g oil) and Phitsanulok (46.37 g/100 g oil), which were selected to test for amino acids and vitamin E. Nineteen amino acids were detected, with lysine, tyrosine, leucine, and glutamic acid predominant. Vitamin E content was $1.02-1.42 \mathrm{mg} / 100 \mathrm{~g}$. For highest quality and greatest benefits to health, sacha inchi should be harvested when the shuck is brown and dry.
\end{abstract}

Keywords: Sacha inchi, Maturity, Split shuck, Fatty acids, Antioxidant activity

\section{Sample identification}

PH, $\mathrm{CH} \quad$ Province code: PH: Phitsanulok, CH: Chiang Rai

CT

PH11, PH12, PH13

CH11, CH12, CH13

$\mathrm{PH} 21, \mathrm{PH} 22, \mathrm{PH} 23$

$\mathrm{CH} 21, \mathrm{CH} 22, \mathrm{CH} 23$
Control

First number: Samples with different Harvest times $\left(1^{\text {st }}\right.$ in April 2016 and $2^{\text {nd }}$ in May 2016)

Second number: Sample with different Maturity stage (1: green, 2: greenish brown, and 3: brown and dried) 
http://wjst.wu.ac.th

\section{Introduction}

Sacha inchi (Plukenetia volubilis L.), or "Inca peanut" or "mountain peanut", is a plant native to Peru. The kernels of sacha inchi are high in protein $(33 \%)$ and oil $(49 \%)$ [1,2]. Intake of sacha inchi oil provides health benefits, as shown by many nutritional studies [3-7]. Sacha inchi oil not only lowers serum triglyceride and cholesterol but also decreases oxidative stress biomarkers [3]. Sacha inchi oil is of particular interest due to its high levels of omega-3 and omega- 6 fatty acids [4,5]. These omega fatty acids are essential fatty acids that provide important health benefits to humans. Omega-3 fatty acids decrease inflammatory markers, blood pressure, and triglycerides [6,7]. Sacha inchi, therefore, has great commercial potential, both as a food in itself and as an ingredient to increase the nutritional value of other foods [8].

Due to growing interest in plant-based sources of omega-3 fatty acids and protein as alternatives to animal-based sources, the demand for products developed from sacha inchi kernels, such as enriched and nutraceutical foods, continues to rise [9]. A thorough search of literature revealed no previous study of the chemical composition and antioxidant activity of sacha inchi in Thailand; thus, the findings in this study should be invaluable.

Sacha inchi growers in Thailand normally harvest the fruits only when they are fully dried with opened and brown shuck. No other maturity indices, such as measuring its oil or moisture content, counting the number of days after bloom, recording the date of harvest, or weighing of the whole fruit, are practiced. Other nuts, such as pecan and almond, are matured when the shucks are still green and split. If these nuts are left on the trees until the shucks become fully brown, dry, and split, they will be exposed to undesirable weather conditions which would cause deterioration to their quality. Since sacha inchi has the same physiological changes as pecan and almond when it is mature, the maturity stages due to colour change and split of shuck are ideal for investigation in order to confirm the normal practice of harvesting for Thai growers and to provide a simple maturity index of sacha inchi.

The aim of this research was to investigate the effects of maturity on chemical composition and antioxidant activity of sacha inchi (Plukenetia volubilis L.) cultivated in the Phitsanulok and Chiang Rai provinces in Thailand.

\section{Materials and methods}

\section{Sacha inchi samples}

The physiological appearance of sacha inchi plants, nut-in-shells, and kernels is shown in Figure 1. Five hundred sacha inchi fruits of each of the 3 maturity stages were collected: 1) green, 2) greenish brown, and 3) brown and dried (Figure 2), and all 3 stages were collected at 2 harvest times $\left(1^{\text {st }}\right.$ harvest in April 2016, and $2^{\text {nd }}$ harvest in May of 2016) to investigate the seasonal variation of agricultural products. The control samples consisted of regularly harvested sacha inchi from both locations which had been stored for 1 year.

Sacha inchi cultivated in the Phitsanulok and Chiang Rai provinces, Thailand, were collected due to the following reasons: (1) Chiang Rai and Phitsanulok were selected as representative of the upper north and lower north areas of Thailand, respectively; (2) Chiang Rai was the $1^{\text {st }}$ sacha inchi cultivated area of Thailand, and sacha inchi cultivation is abundant in Phitsanulok province, and (3) sample collection from both farms at Chiang Rai and Phitsanulok were recommended by the $1^{\text {st }}$ commercial sacha inchi company of Thailand (Tai C.M.S. Standard Industrial Co., Ltd.).

\section{Sample preparation}

After harvesting of the samples, all shucks were removed as soon as possible in order to minimise chances of deterioration. The initial moisture content of the kernels was measured. The 500 nuts-in-shells of each maturity stage were evenly spread in a separated tray and dried at $65^{\circ} \mathrm{C}$ in a hot air oven, with the moisture content measured every $6 \mathrm{~h}$ until a moisture content of $3-5 \%$ was reached. Then, they were cracked by hand, and the kernels were separated from the shells. Floating of kernels were carried out to separate the floated and sunk kernels, and the kernels were dried at $65{ }^{\circ} \mathrm{C}$ in a hot air oven for $3 \mathrm{~h}$. The 
kernel samples were packed into vacuum cans (100 g of kernels per can) and stored at $-18 \pm 2{ }^{\circ} \mathrm{C}$ until analysis.

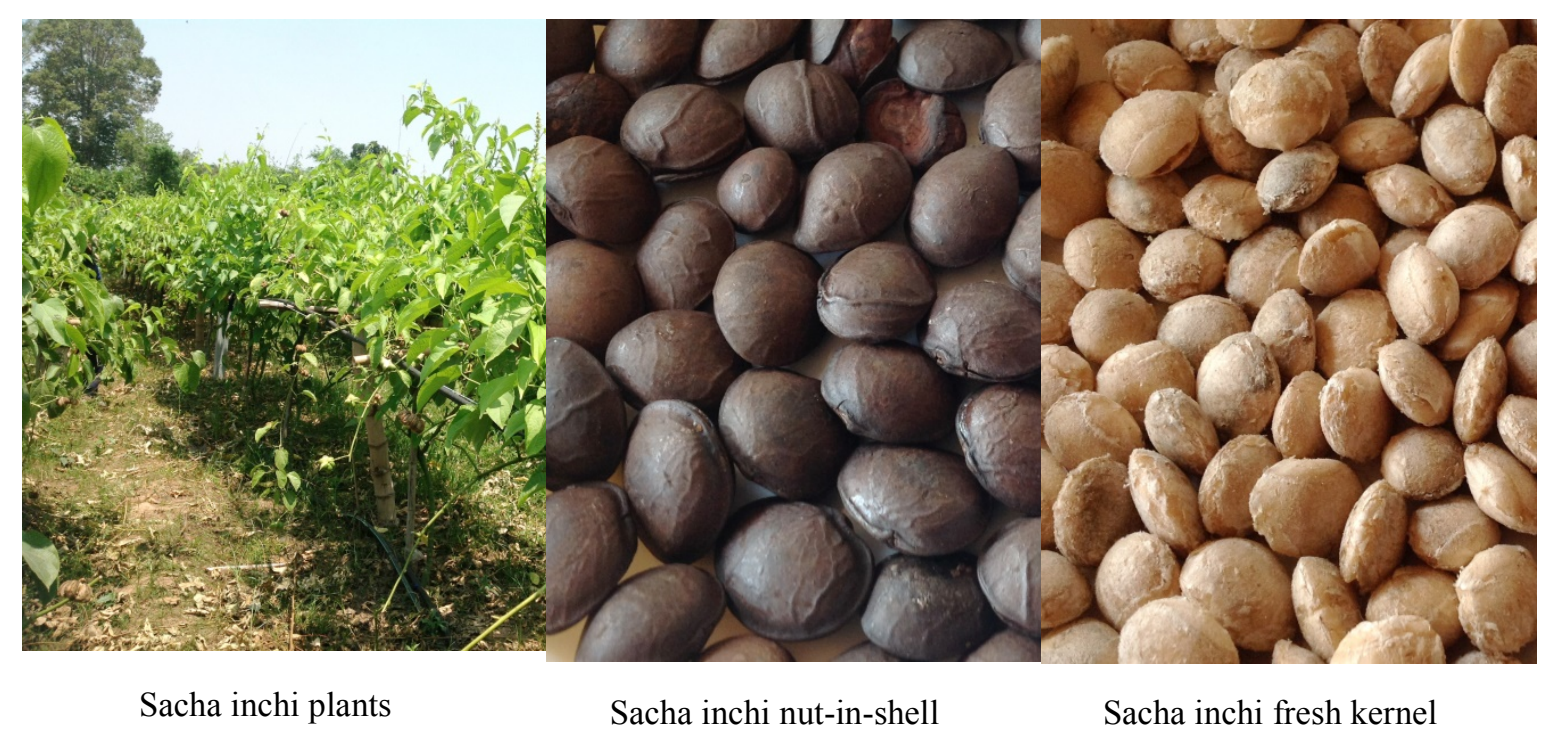

Figure 1 Physiological appearance of sacha inchi plant, nut-in-shells, and kernels.

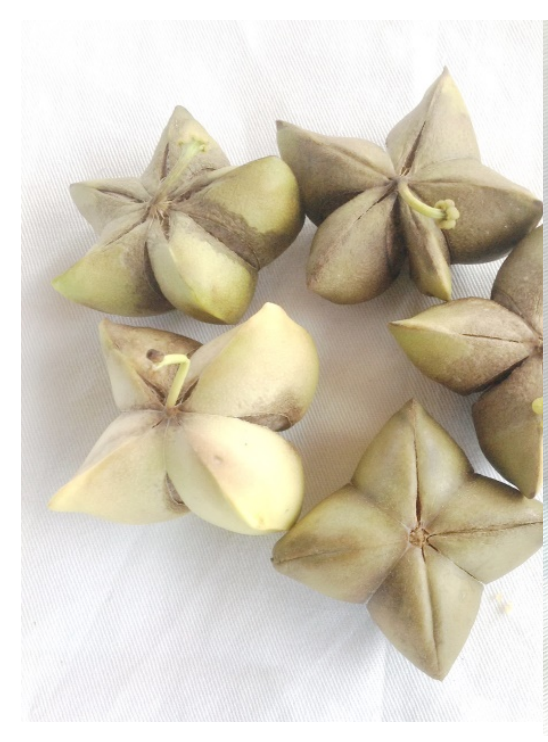

1) Green

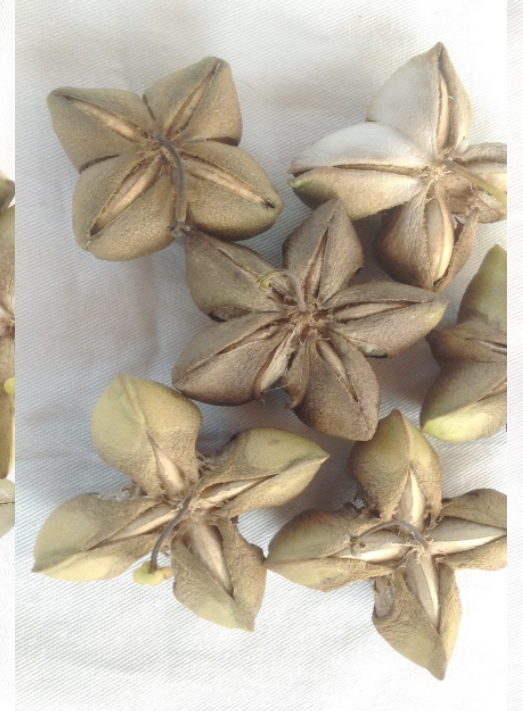

2) Greenish brown

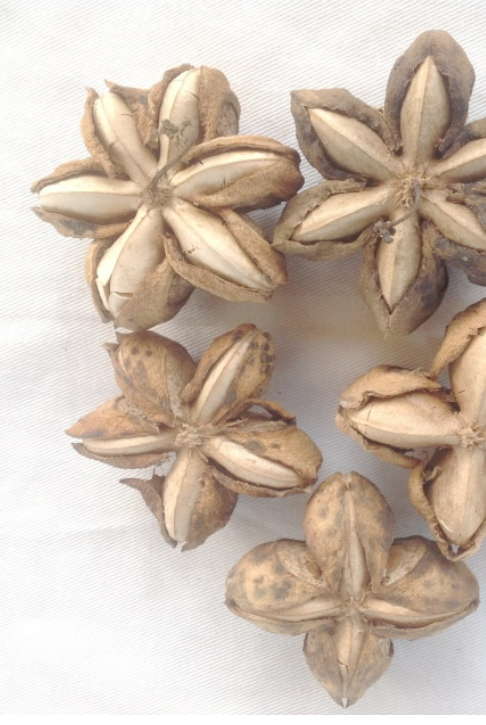

3) Brown and dry

Figure 2 The appearance of 3 different maturity stages of sacha inchi. 
http://wjst.wu.ac.th

\section{Chemical composition}

The chemical composition of each sacha inchi sample was analysed for moisture, protein, oil, fibre, ash, and carbohydrate content using the AOAC [10] procedure.

\section{Total phenolic content}

The TPC of each sacha inchi sample was analysed by the Folin-Ciocalteu calorimetric method, as described by Shen et al. [11]. Briefly, $1.0 \mathrm{~mL}$ of appropriately diluted standard or extract solution was mixed with $0.5 \mathrm{~mL}$ of $0.5 \mathrm{~N}$ of Folin-Ciocalteu reagent. The reaction was neutralised with sodium carbonate $(75 \mathrm{~g} / \mathrm{L})$ and the absorbance of the resultant blue colour after incubation for $2 \mathrm{~h}$ at $23{ }^{\circ} \mathrm{C}$ was determined with a spectrophotometer. The calibration curve was prepared using gallic acid solution, and the total phenolic content and was expressed as mg of gallic acid equivalent (mg GAE) per $100 \mathrm{~g}$ dry weight.

\section{DPPH scavenging activity}

The radical scavenging activity of each sample was analysed using the DPPH-colorimetric method, as described by Murakami et al. [12]. A $200 \mu \mathrm{L}$ sample aliquot was mixed with $800 \mu \mathrm{m}$ of $100 \mathrm{~m} M$ Tris$\mathrm{HCl}$ buffer ( $\mathrm{pH}$ 7.4) and then added to $1 \mathrm{~mL}$ of $500 \mu M$ DPPH in ethanol (for a final concentration of 250 $\mu \mathrm{M})$. This mixture was vigorously shaken and allowed to stand in the dark for 20 min at room temperature. Blanks were prepared without sample solution, and absorbance was measured using a UVVIS spectrophotometer at $517 \mathrm{~nm}$. The free radical scavenging activity was calculated by taking the difference in DPPH radical absorbance at $517 \mathrm{~nm}$ between the blank and the sample, using the following equation:

Radical scavenging activity $(\%)=\frac{C-A}{C} \times 100$

\section{Ferric reducing antioxidant power (FRAP)}

The ferric reducing antioxidant power (FRAP) of each sample was analysed following the methods of Benzie and Strain [13]. The sample extract $(200 \mu \mathrm{L})$ was mixed with $3 \mathrm{~mL}$ of FRAP reagent in test tubes and then mixed with a vortex mixer. A blank sample was prepared for both methanol and deionised water extracted samples. The samples and blanks were all incubated in a water bath for $30 \mathrm{~min}$ at $37^{\circ} \mathrm{C}$, and the absorbance of each sample was measured against the blank at $593 \mathrm{~nm}$. A series of stock solutions at $200,400,800,1200$, and $1600 \mu \mathrm{m}$ were prepared using an aqueous solution of $\mathrm{FeSO}_{4} .7 \mathrm{H}_{2} \mathrm{O}$ as a standard curve. The results obtained were expressed as $\mu \mathrm{M}$ of ferrous equivalent $\mathrm{Fe}$ (II) per $\mathrm{g}$ of sample.

\section{Fatty acid profile, amino acid profile, and vitamin $E$ content}

The fatty acid profile and amino acid profile were analysed using an in-house method TE-CH-208 [14] based on AOAC 996.06, with the limit of detection of $0.01 \mathrm{~g} / 100 \mathrm{~g}$, and the vitamin $\mathrm{E}$ content was also analysed using an in-house method [15] based on the protocol of Khon Kaen AGR. J. 42 SUPPL.1: 2014 in Chiang Rai, Central Laboratory (Thailand) Co. Ltd. Even though the analysis of this part was performed in single analysis, the internal quality control of analysis was carried out to ensure the accuracy of results.

\section{Statistical analysis}

Results were expressed as mean values with standard deviation (SD) from triplicate experiments. Statistical analysis was performed using SPSS v 16.0 (SPSS Inc., Chicago, Illinois, USA), and statistical significance was assessed using analysis of variance followed by Duncan's multiple range test at $95 \%$ confidence level $(P \leq 0.05)$. 


\section{Results and discussion}

\section{Chemical composition}

The chemical composition of the sacha inchi harvested at the 3 maturity stages and 2 locations are presented in Table 1. The initial kernel moisture content of the samples ranged between $4.94 \pm 0.22$ to $36.53 \pm 0.65 \mathrm{~g} / 100 \mathrm{~g}$ and appeared to decrease slightly as the sample changed from one maturity stage to the next, particularly the brown and dry samples, which had significantly lower $(P \leq 0.05)$ moisture content than other maturity stages. Due to rain, the $2^{\text {nd }}$ harvest samples had similar initial moisture content to the $1^{\text {st }}$ harvest samples. After drying, the kernel moisture content of all the samples ranged between $1.54 \pm 0.10$ to $3.72 \pm 0.07 \mathrm{~g} / 100 \mathrm{~g}$. The moisture values were quite similar to the $3.3 \pm 0.3 \mathrm{~g} / 100$ $\mathrm{g}$ reported by Gutiérrez et al. [16]. A higher moisture content of $8.68 \mathrm{~g} / 100 \mathrm{~g}$ for sacha inchi was also reported by Bandioli et al. [17]. The protein content of all the samples from both locations ranged between $16.23 \pm 0.15$ to $18.98 \pm 0.13 \mathrm{~g} / 100 \mathrm{~g}$. Significantly higher protein contents $(18.19 \pm 0.17$ to $18.98 \pm 0.13)$ were recorded in all the samples cultivated in Phitsanulok at all 3 maturity stages. The protein results obtained in this research were lower than the $24.7 \mathrm{~g} / 100 \mathrm{~g}$ and $27-33 \mathrm{~g} / 100 \mathrm{~g}$ obtained from Colombian sacha inchi [16] and Peruvian sacha inchi trees [2], but slightly below the range of 20 $30 \mathrm{~g} / 100 \mathrm{~g}$ reported for flax seed [18]. The oil content ranged from $38.15 \pm 1.01$ to $48.81 \pm 0.52 \mathrm{~g} / 100 \mathrm{~g}$ and is within the range of the $35-60 \mathrm{~g} / 100 \mathrm{~g}$ reported by Hamaker et al. [1]. Bandioli et al. [17] reported a similar oil content of $37.69 \mathrm{~g} / 100 \mathrm{~g}$. Samples CH13, CH12, PH23, CH22, and the control sample CHCT were significantly higher $(P \leq 0.05)$ in oil than all other samples. This might indicate that, in order to get the best quality sacha inchi, the suitable time of harvest is when the shuck is brown, dry, and opened.

The fibre, ash, and carbohydrate content ranged between $14.50-22.24,2.70-3.06$, and $7.70-19.47$ $\mathrm{g} / 100 \mathrm{~g}$, respectively. The fibre content was considerably high; hence, sacha inchi would be a good source of fibre and the associated economic uses. The ash content was similar to the $2.7 \pm 0.04 \mathrm{~g} / 100 \mathrm{~g}$ reported by Betancur-Hoyos et al. [19], and the carbohydrate content was lower than Betancur-Hoyos et al.'s [19] reported $24.5 \mathrm{~g} / 100 \mathrm{~g}$. The lowest fibre content $(14.50 \pm 0.24 \mathrm{~g} / 100 \mathrm{~g})$ was observed in sample PH11. In the case of ash and carbohydrates, the samples from both Phitsanulok and Chang Rai of the $1^{\text {st }}$ harvest at all 3 stages had similar ash content except CH13. Similarly, no significant difference in ash content was observed between all the samples from the $2^{\text {nd }}$ harvest, including the control samples. The carbohydrate content of the $2^{\text {nd }}$ harvest at both locations was similar, with no significant difference $(P>0.05)$. Variation in carbohydrate content was observed only among the samples of the $1^{\text {st }}$ harvest. These variations in composition between this study's samples and the results of other researchers may be attributed to the differences in climate, geographical location, or subspecies [16]. The composition of this study's sacha inchi samples is similar to the Canadian flax seed in terms of protein $(20 \mathrm{~g} / 100 \mathrm{~g})$, fat (41 $\mathrm{g} / 100 \mathrm{~g})$, and ash $(3.4 \mathrm{~g} / 100 \mathrm{~g})$. Therefore, sacha inchi is another promising alternative fat and protein source, given its similarity to flax seed and soybeans.

\section{The total phenolic content and antioxidant activity of sacha inchi}

The total phenolic content (in mg gallic acid/100 g) and antioxidant activity (in mg Trolox equivalent) of all the sacha inchi samples was analysed, and the results are shown in Table 2. The concentration of phenols ranged between $103.18 \pm 1.37$ to $385.00 \pm 1.81 \mathrm{mg}$ gallic acid $/ 100 \mathrm{~g}$. The phenolic content of samples cultivated in both Phitsanulok and Chiang Rai were found to decrease as the sacha inchi fruits changed from the green stage to the brown and dry stage, indicating the effect of maturity stage on total phenolic content. Total phenolic content as a concept has been found to provide many more health benefits than those of essential fatty acids [9].

The DPPH (\%) antioxidant activities and FRAP of the samples ranged between $9.36 \pm 0.09$ to 13.72 $\pm 0.47 \%$ and $6212.01 \pm 227.36$ to $10700.23 \pm 186.90 \mathrm{mg}$ Trolox equivalent, respectively. The antioxidant activity as measured by DPPH was found to decrease as the maturity changed from the green stage to the brown/dry stage. This might be related to the decrease in total phenolic content which is a natural antioxidant in sacha inchi. However, when measured by FRAP, the antioxidant activity increased. These values were higher than the 64.6 to $80 \mathrm{mg} \mathrm{GAE} / 100 \mathrm{~g}$ reported by Chirinos et al. [20] for DPPH. Liu et 
http://wjst.wu.ac.th

al. [9] also reported $12.82 \pm 0.60$ and $8.25 \pm 0.50 \mathrm{mM}$ gallic acid/kg for the $\mathrm{DPPH}$ radical scavenging activity in sacha inchi oil.

Table 1 Chemical composition of sacha inchi harvested at 3 maturity stages and 2 locations.

\begin{tabular}{|c|c|c|c|c|c|c|c|}
\hline \multirow{2}{*}{ Sample } & \multirow{2}{*}{$\begin{array}{c}\text { Initial kernel } \\
\text { moisture }\end{array}$} & \multicolumn{6}{|c|}{ Content (g/100 g dry sample) } \\
\hline & & Moisture* & Protein & Oil & Fibre & Ash & Carbohydrate \\
\hline PHCT & $4.97 \pm 0.09^{f}$ & $2.12 \pm 0.13^{b}$ & $18.64 \pm 0.18^{\mathrm{a}}$ & $41.88 \pm 2.35^{\mathrm{c}}$ & $18.60 \pm 0.11^{\mathrm{bc}}$ & $2.70 \pm 0.04^{b}$ & $16.08 \pm 2.24^{\mathrm{bc}}$ \\
\hline PH11 & $24.84 \pm 0.31^{\mathrm{c}}$ & $3.00 \pm 0.44^{\mathrm{a}}$ & $18.64 \pm 0.27^{\mathrm{a}}$ & $38.15 \pm 1.01^{\mathrm{d}}$ & $14.50 \pm 0.24^{\mathrm{d}}$ & $2.76 \pm 0.05^{\mathrm{b}}$ & $22.88 \pm 0.36^{\mathrm{a}}$ \\
\hline PH12 & $26.27 \pm 0.10^{\mathrm{b}}$ & $2.81 \pm 0.21^{\mathrm{a}}$ & $18.98 \pm 0.13^{\mathrm{a}}$ & $41.86 \pm 1.12^{\mathrm{c}}$ & $18.45 \pm 0.22^{\mathrm{bc}}$ & $2.72 \pm 0.03^{b}$ & $15.18 \pm 1.19^{\mathrm{cd}}$ \\
\hline PH13 & $5.25 \pm 0.10^{\mathrm{ef}}$ & $1.54 \pm 0.10^{\mathrm{c}}$ & $17.65 \pm 0.39^{b}$ & $42.71 \pm 2.93^{\mathrm{c}}$ & $18.92 \pm 0.07^{\mathrm{b}}$ & $2.78 \pm 0.13^{b}$ & $16.31 \pm 3.20^{\mathrm{bc}}$ \\
\hline $\mathrm{CHCT}$ & $4.94 \pm 0.22^{\mathrm{f}}$ & $1.56 \pm 0.07^{\mathrm{c}}$ & $16.96 \pm 0.68^{\mathrm{b}}$ & $48.81 \pm 0.52^{\mathrm{a}}$ & $22.24 \pm 1.11^{\mathrm{a}}$ & $2.71 \pm 0.08^{\mathrm{b}}$ & $7.70 \pm 1.14^{\mathrm{e}}$ \\
\hline CH11 & $28.19 \pm 0.48^{\mathrm{a}}$ & $2.05 \pm 0.20^{\mathrm{b}}$ & $17.31 \pm 0.11^{\mathrm{b}}$ & $40.94 \pm 1.50^{\mathrm{cd}}$ & $17.47 \pm 1.06^{\mathrm{c}}$ & $2.77 \pm 0.15^{b}$ & $19.47 \pm 2.00^{\mathrm{ab}}$ \\
\hline $\mathrm{CH} 12$ & $21.25 \pm 0.79^{\mathrm{d}}$ & $2.11 \pm 0.25^{\mathrm{b}}$ & $17.54 \pm 0.46^{\mathrm{b}}$ & $44.20 \pm 0.40^{\mathrm{bc}}$ & $21.60 \pm 1.38^{\mathrm{a}}$ & $2.82 \pm 0.10^{\mathrm{b}}$ & $11.73 \pm 1.35^{\mathrm{d}}$ \\
\hline $\mathrm{CH} 13$ & $5.79 \pm 0.27^{\mathrm{e}}$ & $1.42 \pm 0.12^{\mathrm{c}}$ & $17.25 \pm 0.94^{\mathrm{b}}$ & $47.26 \pm 2.49^{\mathrm{ab}}$ & $17.16 \pm 0.62^{\mathrm{c}}$ & $3.06 \pm 0.15^{\mathrm{a}}$ & $13.86 \pm 4.06^{\mathrm{cd}}$ \\
\hline PHCT & $4.97 \pm 0.09^{\mathrm{D}}$ & $2.12 \pm 0.13^{\mathrm{C}}$ & $18.64 \pm 0.18^{\mathrm{A}}$ & $41.88 \pm 2.35^{\mathrm{CD}}$ & $18.60 \pm 0.11^{\mathrm{CD}}$ & $2.70 \pm 0.04^{\mathrm{NS}}$ & $16.08 \pm 2.24^{\mathrm{A}}$ \\
\hline $\mathrm{PH} 21$ & $36.36 \pm 0.36^{\mathrm{A}}$ & $2.78 \pm 0.21^{\mathrm{B}}$ & $18.59 \pm 0.39^{\mathrm{A}}$ & $42.92 \pm 0.79^{\mathrm{C}}$ & $17.27 \pm 1.01^{\mathrm{DE}}$ & $2.77 \pm 0.11^{\mathrm{NS}}$ & $15.66 \pm 1.43^{\mathrm{A}}$ \\
\hline PH22 & $36.37 \pm 0.57^{\mathrm{A}}$ & $2.16 \pm 0.58^{\mathrm{C}}$ & $18.22 \pm 0.15^{\mathrm{A}}$ & $40.09 \pm 0.91^{\mathrm{D}}$ & $22.19 \pm 1.56^{\mathrm{A}}$ & $2.78 \pm 0.03^{\mathrm{NS}}$ & $14.57 \pm 1.64^{\mathrm{A}}$ \\
\hline $\mathrm{PH} 23$ & $6.37 \pm 0.05^{\mathrm{C}}$ & $1.91 \pm 0.08^{\mathrm{CD}}$ & $18.19 \pm 0.17^{\mathrm{A}}$ & $46.37 \pm 0.98^{\mathrm{B}}$ & $16.62 \pm 1.27^{\mathrm{E}}$ & $2.73 \pm 0.10^{\mathrm{NS}}$ & $14.17 \pm 0.76^{\mathrm{A}}$ \\
\hline CHCT & $4.94 \pm 0.22^{\mathrm{D}}$ & $1.56 \pm 0.07^{\mathrm{D}}$ & $16.96 \pm 0.68^{\mathrm{B}}$ & $48.81 \pm 0.52^{\mathrm{A}}$ & $22.24 \pm 1.11^{\mathrm{A}}$ & $2.71 \pm 0.08^{\mathrm{NS}}$ & $7.70 \pm 1.14^{\mathrm{B}}$ \\
\hline $\mathrm{CH} 21$ & $36.53 \pm 0.65^{\mathrm{A}}$ & $2.14 \pm 0.07^{\mathrm{C}}$ & $16.43 \pm 0.05^{\mathrm{BC}}$ & $42.24 \pm 0.96^{\mathrm{CD}}$ & $20.30 \pm 0.50^{\mathrm{BC}}$ & $2.81 \pm 0.03^{\mathrm{NS}}$ & $16.08 \pm 1.52^{\mathrm{A}}$ \\
\hline $\mathrm{CH} 22$ & $36.21 \pm 0.30^{\mathrm{A}}$ & $2.14 \pm 0.10^{\mathrm{C}}$ & $16.23 \pm 0.15^{\mathrm{C}}$ & $46.09 \pm 0.56^{\mathrm{B}}$ & $18.82 \pm 0.52^{\mathrm{CD}}$ & $2.77 \pm 0.07^{\mathrm{NS}}$ & $13.94 \pm 1.08^{\mathrm{A}}$ \\
\hline $\mathrm{CH} 23$ & $28.34 \pm 0.19^{\mathrm{B}}$ & $3.72 \pm 0.07^{\mathrm{A}}$ & $16.51 \pm 0.17^{\mathrm{BC}}$ & $42.05 \pm 1.09^{\mathrm{CD}}$ & $20.67 \pm 0.62^{\mathrm{AB}}$ & $2.85 \pm 0.11^{\mathrm{NS}}$ & $14.20 \pm 1.26^{\mathrm{A}}$ \\
\hline
\end{tabular}

*Moisture after drying

Mean values with different superscript letters in column (same harvest time) indicate significant difference $(P \leq$ $0.05)$.

$\mathrm{PH}, \mathrm{CH}$

Province code: PH: Phitsanulok, CH: Chiang Rai

$\mathrm{CT}$

Control

PH1 1, PH12, PH13

First number: Samples with different Harvest times ( $1^{\text {st }}$ in April 2016 and $2^{\text {nd }}$ in May 2016)

$\mathrm{CH} 11, \mathrm{CH} 12, \mathrm{CH} 13$

$\mathrm{PH} 21, \mathrm{PH} 22, \mathrm{PH} 23$

Second number: Sample with different Maturity stage (1: green, 2: greenish brown, and 3:

$\mathrm{CH} 21, \mathrm{CH} 22, \mathrm{CH} 23$

brown and dried) 
http://wjst.wu.ac.th

Table 2 Total phenolic content and antioxidant activity of sacha inchi harvested at 3 maturity stages and 2 locations.

\begin{tabular}{|c|c|c|c|}
\hline \multirow[b]{2}{*}{ Sample } & \multirow{2}{*}{$\begin{array}{l}\text { Total Phenolic Content } \\
\text { (mg gallic acid } / 100 \text { g wb.) }\end{array}$} & \multicolumn{2}{|c|}{ Antioxidant activity } \\
\hline & & DPPH (\%) & $\begin{array}{c}\text { FRAP } \\
\text { (mg Trolox equivalent) }\end{array}$ \\
\hline PHCT & $120.31 \pm 1.44^{\mathrm{e}}$ & $12.23 \pm 0.28^{\mathrm{abc}}$ & $5892.69 \pm 79.83^{\text {ef }}$ \\
\hline PH11 & $385.00 \pm 1.81^{\mathrm{a}}$ & $9.36 \pm 0.09^{\mathrm{f}}$ & $10700.23 \pm 186.90^{\mathrm{a}}$ \\
\hline PH12 & $311.30 \pm 1.19^{\mathrm{b}}$ & $11.49 \pm 0.47^{\mathrm{cd}}$ & $10079.33 \pm 377.57^{b}$ \\
\hline PH13 & $103.18 \pm 1.37^{\mathrm{f}}$ & $11.68 \pm 0.84^{\mathrm{bcd}}$ & $6212.01 \pm 227.36^{\mathrm{e}}$ \\
\hline CHCT & $116.24 \pm 1.81^{\mathrm{e}}$ & $12.56 \pm 0.05^{\mathrm{ab}}$ & $6167.66 \pm 81.29^{\mathrm{ef}}$ \\
\hline CH11 & $263.03 \pm 0.69^{d}$ & $10.47 \pm 0.56^{\mathrm{e}}$ & $9006.06 \pm 358.00^{\mathrm{c}}$ \\
\hline $\mathrm{CH} 12$ & $272.13 \pm 3.14^{\mathrm{c}}$ & $10.84 \pm 0.74^{\mathrm{de}}$ & $8562.56 \pm 85.54^{\mathrm{d}}$ \\
\hline $\mathrm{CH} 13$ & $107.13 \pm 8.56^{\mathrm{f}}$ & $12.84 \pm 0.33^{\mathrm{a}}$ & $5803.99 \pm 40.65^{\mathrm{f}}$ \\
\hline PHCT & $120.31 \pm 1.44^{\mathrm{F}}$ & $12.23 \pm 0.28^{\mathrm{B}}$ & $5892.69 \pm 79.83^{\mathrm{H}}$ \\
\hline $\mathrm{PH} 21$ & $380.54 \pm 2.47^{\mathrm{A}}$ & $11.31 \pm 0.56^{\mathrm{C}}$ & $9795.49 \pm 81.29^{\mathrm{A}}$ \\
\hline $\mathrm{PH} 22$ & $337.41 \pm 4.28^{\mathrm{B}}$ & $10.15 \pm 0.14^{\mathrm{D}}$ & $9147.98 \pm 66.97^{\mathrm{B}}$ \\
\hline $\mathrm{PH} 23$ & $156.20 \pm 8.08^{\mathrm{E}}$ & $13.72 \pm 0.47^{\mathrm{A}}$ & $6522.46 \pm 40.65^{\mathrm{F}}$ \\
\hline $\mathrm{CHCT}$ & $116.24 \pm 1.81^{\mathrm{F}}$ & $12.56 \pm 0.05^{\mathrm{B}}$ & $6167.66 \pm 81.29^{\mathrm{G}}$ \\
\hline $\mathrm{CH} 21$ & $243.64 \pm 1.19^{\mathrm{C}}$ & $10.43 \pm 0.61^{\mathrm{D}}$ & $7764.26 \pm 85.54^{\mathrm{C}}$ \\
\hline $\mathrm{CH} 22$ & $245.62 \pm 0.68^{\mathrm{C}}$ & $11.17 \pm 0.33^{C}$ & $7551.38 \pm 15.36^{\mathrm{D}}$ \\
\hline $\mathrm{CH} 23$ & $196.16 \pm 1.19^{\mathrm{D}}$ & $13.35 \pm 0.10^{\mathrm{A}}$ & $7036.92 \pm 46.09^{\mathrm{E}}$ \\
\hline \multicolumn{4}{|c|}{$\begin{array}{l}\text { Mean values with different superscript letters in column (same harvest time) indicate significant difference }(P \leq \\
0.05) \text {. } \\
\text { PH, CH }\end{array}$} \\
\hline $\mathrm{CT}$ & \multicolumn{3}{|l|}{$\begin{array}{l}\text { Province coc } \\
\text { Control }\end{array}$} \\
\hline $\begin{array}{l}\text { PH11, PH12, PH13 } \\
\text { CH11, CH12, CH13 } \\
\text { PH21, PH22, PH23 } \\
\text { CH21, CH22, CH23 }\end{array}$ & \multicolumn{3}{|c|}{$\begin{array}{l}\text { First number: Samples with different Harvest times ( } 1^{\text {st }} \text { in April } 2016 \text { and } 2^{\text {nd }} \text { in May } \\
\text { 2016) } \\
\text { Second number: Sample with different Maturity stage (1: green, 2: greenish brown, and 3: } \\
\text { brown and dried) }\end{array}$} \\
\hline
\end{tabular}


http://wjst.wu.ac.th

Table 3 Fatty acid composition of sacha inchi harvested at 3 maturity stages and 2 locations.

\begin{tabular}{|c|c|c|c|c|c|c|c|c|c|c|c|c|}
\hline \multirow[b]{2}{*}{ Samples } & \multicolumn{12}{|c|}{ Fatty acid content (g/100 g wb.) } \\
\hline & $\begin{array}{l}\text { Palmiti } \\
\text { c acid } \\
\text { (C16:0) }\end{array}$ & $\begin{array}{c}\text { Heptadecanoi } \\
\text { c acid } \\
\text { (C17:0) }\end{array}$ & $\begin{array}{c}\text { Stearic } \\
\text { acid } \\
\text { (C18:0) }\end{array}$ & $\begin{array}{l}\text { Arachidic } \\
\text { acid } \\
\text { (C20:0) }\end{array}$ & $\begin{array}{l}\text { Palmitoleic } \\
\text { acid } \\
\text { (C16:1n7) }\end{array}$ & $\begin{array}{c}\text { cis-10- } \\
\text { Heptadecenoic } \\
\text { acid } \\
(C 17: 1 \mathrm{n} 10)\end{array}$ & $\begin{array}{c}\text { cis-9-Oleic } \\
\text { acid } \\
\text { (C18:1n9c) }\end{array}$ & $\begin{array}{c}\text { cis-11- } \\
\text { Eicosenoic } \\
\text { acid } \\
(C 20: 1 n 11) \\
\end{array}$ & $\begin{array}{l}\text { cis-9,12- } \\
\text { Linoleic acid } \\
(C 18: 2 n 6)\end{array}$ & $\begin{array}{l}\text { gamma- } \\
\text { Linolenic } \\
\text { acid } \\
\text { (C18:3n6) }\end{array}$ & $\begin{array}{c}\text { alpha- } \\
\text { Linolenic } \\
\text { acid } \\
\text { (C18:3n3) }\end{array}$ & $\begin{array}{c}\text { cis-11,14- } \\
\text { Eicosadienoic } \\
\text { acid } \\
(\mathbf{C 2 0}: 2)\end{array}$ \\
\hline PHCT & 1.78 & 0.02 & 1.32 & 0.06 & 0.02 & ND & 4.40 & 0.15 & 17.14 & 0.05 & 15.86 & ND \\
\hline PH11 & 1.74 & 0.03 & 1.20 & 0.05 & 0.02 & 0.01 & 3.49 & 0.12 & 15.33 & 0.04 & 13.43 & ND \\
\hline PH12 & 1.68 & 0.03 & 1.22 & 0.05 & 0.02 & 0.01 & 4.08 & 0.12 & 15.36 & 0.04 & 13.25 & ND \\
\hline PH13 & 1.78 & 0.03 & 1.30 & 0.06 & 0.02 & 0.01 & 4.39 & 0.12 & 16.29 & 0.04 & 13.18 & ND \\
\hline CHCT & 1.58 & 0.02 & 1.24 & 0.05 & 0.02 & ND & 3.87 & 0.14 & 15.35 & 0.05 & 15.80 & ND \\
\hline CH11 & 1.68 & 0.03 & 1.26 & 0.05 & 0.02 & 0.01 & 3.34 & 0.14 & 16.18 & 0.05 & 15.93 & 0.01 \\
\hline $\mathrm{CH} 12$ & 1.76 & 0.03 & 1.38 & 0.06 & 0.02 & 0.01 & 3.58 & 0.16 & 17.71 & 0.06 & 18.21 & 0.01 \\
\hline $\mathrm{CH} 13$ & 1.56 & 0.02 & 1.37 & 0.06 & 0.02 & ND & 3.66 & 0.14 & 15.59 & 0.05 & 14.93 & 0.01 \\
\hline PH21 & 2.14 & 0.04 & 1.36 & 0.06 & 0.03 & 0.02 & 5.48 & 0.11 & 17.02 & 0.03 & 10.15 & ND \\
\hline $\mathrm{PH} 22$ & 2.03 & 0.04 & 1.29 & 0.06 & 0.03 & 0.02 & 5.22 & 0.10 & 16.21 & 0.03 & 9.87 & ND \\
\hline PH23 & 2.35 & 0.04 & 1.59 & 0.07 & 0.03 & 0.02 & 5.98 & 0.14 & 19.71 & 0.05 & 13.96 & ND \\
\hline $\mathrm{CH} 21$ & 2.25 & 0.04 & 1.70 & 0.08 & 0.02 & 0.02 & 5.69 & 0.14 & 20.34 & 0.05 & 14.07 & ND \\
\hline $\mathrm{CH} 22$ & 1.94 & 0.04 & 1.46 & 0.06 & 0.02 & 0.02 & 4.83 & 0.12 & 17.82 & 0.04 & 12.32 & ND \\
\hline $\mathrm{CH} 22$ & 2.04 & 0.03 & 1.51 & 0.07 & 0.03 & 0.02 & 4.45 & 0.12 & 18.02 & 0.04 & 12.93 & ND \\
\hline
\end{tabular}

$\mathrm{PH}, \mathrm{CH}$

CT

PH1 1, PH12, PH13

CH11, CH12, CH13

$\mathrm{PH} 21, \mathrm{PH} 22, \mathrm{PH} 23$

$\mathrm{CH} 21, \mathrm{CH} 22, \mathrm{CH} 23$
Province code: PH: Phitsanulok, CH: Chiang Rai

Control

First number: Samples with different Harvest times $\left(1^{\text {st }}\right.$ in April 2016 and $2^{\text {nd }}$ in May 2016)

Second number: Sample with different Maturity stage (1: green, 2: greenish brown, and 3: brown and dried)

\section{Fatty acid composition and profiles of sacha inchi}

The fatty acid composition of sacha inchi harvested at the 3 maturity stages and 2 locations is displayed in Table 3. The major fatty acids identified were cis-9, 12-linoleic acid (15.33 to $20.34 \mathrm{~g} / 100$ g), alpha-linolenic acid (9.87 to $18.21 \mathrm{~g} / 100 \mathrm{~g})$, cis-9-oleic acid (3.34 to $5.98 \mathrm{~g} / 100 \mathrm{~g}$ ), palmitic acid (1.58 to $2.35 \mathrm{~g} / 100 \mathrm{~g}$ ), and steric acid (1.20 to $1.70 \mathrm{~g} / 100 \mathrm{~g})$. Betancur-Hoyos et al. [19] reported similar palmitic acid $(1.85 \pm 0.001 \%)$, stearic acid $(1.26 \pm 0.002 \%)$, palmitoleic acid $(0.03 \pm 0.001 \%)$, and oleic acid $(3.4 \pm 0.009 \%)$ content, but lower linoleic acid $(13.7 \pm 0.05 \%)$ and $\alpha$-linolenic acid $(19.9 \pm 0.06 \%)$ content, in Colombian sacha inchi seeds. Similarly, Chirinos et al. [20] reported palmitic, stearic, oleic, linoleic, and $\alpha$-linolenic acids in the ranges of $1.7-2.1 \mathrm{~g} / 100 \mathrm{~g}, 1.1-1.3 \mathrm{~g} / 100 \mathrm{~g}, 3.5-4.7 \mathrm{~g} / 100 \mathrm{~g}, 12.4$ $14.1 \mathrm{~g} / 100 \mathrm{~g}$, and $13.2-16 \mathrm{~g} / 100 \mathrm{~g}$, respectively, for 16 different cultivars of sacha inchi seeds from Peru. Interestingly, Bondioli et al. [17] reported higher fatty acid levels from sacha inchi oil (rather than seeds), specifically oleic $(8.77 \%)$, stearic $(2.65 \%)$, palmitic $(3.79 \%)$, linoleic $(33.67 \%)$, and linolenic acid $(50.73 \%)$. It is worth noting that the linoleic acid content of the current study's sacha inchi samples (15.33 to $20.34 \%)$ were competitive with those of flax seed $(15.30 \%)$, chia seed (18.89\%) [18], and Camelina seed (14.8\%) [21].

In general, the samples of the $2^{\text {nd }}$ harvest showed slightly more palmitic acid, heptadecanoic acid, steric acid, arachidic acid, palmitic acid, cis-9-oleic acid, and $\alpha$-linolenic acid. Cis-11, 14-eicosadienoic acid was found exclusively in the samples of the 3 stages of harvest 1, cultivated in Chiang Rai; specifically, only $0.01 \mathrm{~g} / 100 \mathrm{~g}$ was present. Fatty acid content of sacha inchi seeds is generally found to be lower than that of sacha inchi oil. Both sacha inchi seeds and sacha inchi oil can serve as viable alternative sources of linoleic and linolenic acids in the diet or for nutraceuticals [9].

The fatty acid profiles of the sacha inchi samples are shown in Table 4. The polyunsaturated fatty acid (PUFA) of the sacha inchi amounted to 27.21 to $35.99 \mathrm{~g} / 100 \mathrm{~g}$, and the highest PUFA content was obtained in CH12 (35.99 g/100 g), followed by CH21 (34.46 g/100 g), CH23 (33.74 g/100 g), and CH12 $(32.18 \mathrm{~g} / 100 \mathrm{~g})$. The monounsaturated fatty acid (MUFA) content ranged between 3.51 to $6.17 \mathrm{~g} / 100 \mathrm{~g}$, and the highest content was observed in PH23 (6.17 g/100 g), CH21 (5.88 g/100 g), PH21 (5.65 g/100 g), PH22 (5.37 g/100 g), and CH22 (5.00 g/100 g), in that order. On the other hand, a low saturated fatty acid 
http://wjst.wu.ac.th

(SFA) content was found (2.99 to $4.09 \mathrm{~g} / 100 \mathrm{~g})$. The results were below the ranges of $78.0-81.1 \%, 10.8$ - $13.2 \%$, and $7.9-9.1 \%$ for PUFA, MUFA, and SFA, respectively, for the 16 cultivars of sacha inch seed presented by Chirinos et al. [20] and the $84.2 \%, 9.1 \%$, and $6.8 \%$, for PUFA, MUFA, and SFA, respectively, presented by Gutiérrez et al. [16]. These differences may be due to the quantification methods for the sample analysis. The PUFAs named alpha-linolenic acid (ALA, C18:3, omega-3) and linoleic acid (LA, C18:2, omega-6) exert beneficial effects on human health by preventing diseases such as cancer, arthritis, heart disease, and diabetes [8].

No trans-fat was detected in any of the samples, and omega-6 (15401.58 to $20383.17 \mathrm{mg} / 100 \mathrm{~g})$ was slightly higher than omega-3 (9874.20 to $18209.31 \mathrm{mg} / 100 \mathrm{~g})$ in all the samples. The omega-6/omega-3 ratio was $1.12-1.56$. The ratio of omega-3 and 6 to omega-9 fatty acid was about 1.4 to 4.5 . Sacha inchi has potential as a source to increase the intake of omega-3 and omega- 6 fatty acids, although the omega- 3 and omega- 6 content is relatively lower than the 1:4 ratio recommended by the World Health Organization (WHO) [9]. Intake of omega-3 and omega-6 essential fatty acids has been reported to help reduce the risk of heart diseases, arthritis, diabetes, hypertension, attention deficit disorder (ADD), hyperactivity, and inflammatory skin diseases [19].

Table 4 Fatty acid profiles of sacha inchi harvested at 3 maturity stages and 2 locations.

\begin{tabular}{|c|c|c|c|c|c|c|c|c|c|}
\hline \multirow[b]{2}{*}{ Samples } & \multicolumn{9}{|c|}{ Content (g/100 g wb) } \\
\hline & $\begin{array}{c}\text { SFA } \\
(\mathrm{g} / 100 \mathrm{~g})\end{array}$ & $\begin{array}{c}\text { MUFA } \\
\text { (g/100 g) }\end{array}$ & $\begin{array}{c}\text { PUFA } \\
(\mathrm{g} / 100 \mathrm{~g})\end{array}$ & $\begin{array}{c}\text { UFA } \\
(\mathrm{g} / 100 \mathrm{~g})\end{array}$ & PMS ratio & $\begin{array}{l}\text { Trans fat } \\
\text { (g/100 g) }\end{array}$ & $\begin{array}{c}\text { Omega-3 } \\
(\mathrm{mg} / 100 \mathrm{~g})\end{array}$ & $\begin{array}{c}\text { Omega-6 } \\
(\mathrm{mg} / 100 \mathrm{~g})\end{array}$ & $\begin{array}{c}\text { Omega-9 } \\
(\mathrm{mg} / 100 \mathrm{~g})\end{array}$ \\
\hline PHCT & 3.18 & 4.57 & 33.06 & 37.63 & $10.40: 1.44: 1$ & ND & 15860.14 & 17189.89 & 4397.46 \\
\hline PH11 & 3.03 & 3.65 & 28.81 & 32.46 & $9.51: 1.20: 1$ & ND & 13431.39 & 15370.80 & 3490.80 \\
\hline PH12 & 2.99 & 4.23 & 28.66 & 32.89 & 9.59:1.41:1 & ND & 13248.29 & 15403.58 & 4075.72 \\
\hline PH13 & 3.17 & 4.55 & 29.52 & 34.07 & $9.31: 1.44: 1$ & ND & 13183.06 & 16329.85 & 4386.73 \\
\hline CHCT & 2.90 & 4.04 & 31.21 & 35.25 & $10.76: 1.39: 1$ & ND & 15802.68 & 15401.16 & 3871.92 \\
\hline CH11 & 3.03 & 3.51 & 32.18 & 35.69 & 10.62:1.16:1 & ND & 15933.75 & 16235.79 & 3337.47 \\
\hline $\mathrm{CH} 12$ & 3.23 & 3.77 & 35.99 & 39.76 & $11.14: 1.17: 1$ & ND & 18209.31 & 17766.76 & 3576.37 \\
\hline $\mathrm{CH} 13$ & 3.02 & 3.83 & 30.59 & 34.42 & $10.13: 1.27: 1$ & ND & 14934.22 & 15638.59 & 3664.51 \\
\hline PH21 & 3.60 & 5.65 & 27.21 & 32.86 & $7.56: 1.57: 1$ & ND & 10150.25 & 17056.22 & 5484.19 \\
\hline PH22 & 3.43 & 5.37 & 26.13 & 31.50 & $7.62: 1.57: 1$ & ND & 9874.20 & 16251.91 & 5216.85 \\
\hline PH23 & 4.06 & 6.17 & 33.74 & 39.91 & $8.31: 1.52: 1$ & ND & 13962.76 & 19766.16 & 5979.99 \\
\hline $\mathrm{CH} 21$ & 4.09 & 5.88 & 34.46 & 40.34 & $8.43: 1.44: 1$ & ND & 14070.75 & 20383.17 & 5688.45 \\
\hline $\mathrm{CH} 22$ & 3.51 & 5.00 & 30.18 & 35.18 & $8.60: 1.42: 1$ & ND & 12317.60 & 17861.22 & 4827.60 \\
\hline $\mathrm{CH} 22$ & 3.66 & 4.62 & 30.99 & 35.62 & $8.47: 1.26: 1$ & ND & 12927.71 & 18059.54 & 4450.38 \\
\hline
\end{tabular}

$\mathrm{PH}, \mathrm{CH}$

CT

PH1 1, PH12, PH13

CH11, CH12, CH13

PH21, $\mathrm{PH} 22, \mathrm{PH} 23$

$\mathrm{CH} 21, \mathrm{CH} 22, \mathrm{CH} 23$
Province code: PH: Phitsanulok, CH: Chiang Rai

Control

First number: Samples with different Harvest times $\left(1^{\text {st }}\right.$ in April 2016 and $2^{\text {nd }}$ in May 2016)

Second number: Sample with different Maturity stage (1: green, 2: greenish brown, and 3: brown and dried)

\section{Amino acid composition of sacha inchi}

Table 5 shows the amino acid composition of the 2 sacha inchi samples (PH13 and CH13) selected for their high oil content. The amino acid content of sacha inchi harvested from Phitsanulok tended to be higher compared to those harvested from Chiang Rai. The sacha inchi cultivated in both locations were rich in both essential and non-essential amino acids. The predominant essential amino acids found were lysine (4771 to $5384 \mathrm{mg} / 100 \mathrm{~g}$ ), tyrosine (3780 to $3273 \mathrm{mg} / 100 \mathrm{~g}$ ), leucine (3043 to $2959 \mathrm{mg} / 100 \mathrm{~g}$ ), isoleucine (1387 to $1714 \mathrm{mg} / 100 \mathrm{~g})$, histidine (1183 to $1427 \mathrm{mg} / 100 \mathrm{~g})$, phenylalanine (1221 to 1550 $\mathrm{mg} / 100 \mathrm{~g})$, and valine $(1050$ to $1284 \mathrm{mg} / 100 \mathrm{~g})$. The predominant non-essential amino acids were 
http://wjst.wu.ac.th

glutamic acid (1593 to $2027 \mathrm{mg} / 100 \mathrm{~g}$ ), aspartic acid (1215 to $1495 \mathrm{mg} / 100 \mathrm{~g}$ ), and glycine (967 to 1069 $\mathrm{mg} / 100 \mathrm{~g}$ ). The samples had lesser amounts of threonine (325 to $362 \mathrm{mg} / 100 \mathrm{~g}$ ), methionine (120 to 147 $\mathrm{mg} / 100 \mathrm{~g}$ ), hydroxyproline (19 to $58 \mathrm{mg} / 100 \mathrm{~g}$ ), and hydroxylysine $(<5.0 \mathrm{mg} / 100 \mathrm{~g})$, followed by alanine, serine, and proline.

Guillen et al. [4] reported that the Peru sacha inchi had protein content of $27 \mathrm{~g} / 100 \mathrm{~g}$ and the predominant amino acids were cystine, tyrosine, threonine, and tryptophan, which were different from this study. This could be due to differences in variety, location, climate, farm management, harvest period, and analytical method [20].

In comparison with other protein rich seeds, sacha inchi has similar alanine content to camelina (4.61\%, equiv $0.462 \mathrm{mg} / 100 \mathrm{~g})$, rape seeds $(4.0 \%)$, and soya seeds $(4.8 \%)$, and similar aspartic acid (12.7 and $12.4 \%$ ) and glutamic acid (19.0 and $26.4 \%$ ) content to soya and flax seeds, respectively. On the other hand, higher contents of lysine, leucine, tyrosine, cysteine, and valine were obtained from sacha inchi than from camelina, rape, soya, or flax seeds [21,22].

Table 5 Amino acid composition and vitamin E ( $\alpha$-Tocopherol) content of the selected samples.

\begin{tabular}{lcccc}
\hline \multirow{2}{*}{ Amino acids } & \multicolumn{3}{c}{ Content (mg/100 g wb) } \\
\cline { 2 - 5 } & PHCT & PH13 & CHCT & CH13 \\
\hline Alanine & 458 & 482 & 407 & 397 \\
Aspartic acid & 1495 & 1359 & 1215 & 1234 \\
Cystine & 1378 & 1883 & 1555 & 1723 \\
Glutamic acid & 2027 & 1838 & 1593 & 1630 \\
Glycine & 1065 & 1069 & 967 & 1050 \\
Histidine & 1427 & 1410 & 1183 & 1413 \\
Hydroxylysine & $<5.00$ & $<5.00$ & $<5.00$ & $<5.00$ \\
Hydroxyproline & 19 & 58 & 43 & 20 \\
Isoleucine & 1714 & 1671 & 1387 & 1391 \\
Leucine & 2959 & 3043 & 2434 & 2479 \\
Lysine & 5132 & 5180 & 4771 & 5384 \\
Methionine & 147 & 140 & 120 & 123 \\
Phenylalanine & 1550 & 1594 & 1221 & 1243 \\
Proline & 688 & 640 & 554 & 569 \\
Serine & 437 & 438 & 400 & 412 \\
Threonine & 362 & 356 & 325 & 343 \\
Tryptophan & 689 & 805 & 607 & 708 \\
Tyrosine & 3458 & 3780 & 3273 & 3304 \\
Valine & 1284 & 1211 & 1050 & 1085 \\
Vitamin E $(\alpha-$ Tocopherol) content & 1.31 & 1.02 & 1.18 & 1.42 \\
\hline
\end{tabular}

PHCT: Control from Phitsanulok province

PH13: Sample from Phitsanulok province, harvested 1, maturity stage 3

CHCT: Control from Chiang Rai province

CH13: Sample from Chiang Rai province, harvested 1, maturity stage 3

\section{Vitamin E content}

The vitamin E content ( $\alpha$-Tocopherol) of the sacha inchi samples is also displayed in Table 5. The sample cultivated in Chiang Rai (CH13) had slightly higher $\alpha$-tocopherol $(1.42 \mathrm{mg} / 100 \mathrm{~g})$ than what was found in the sample PH13 cultivated in Phitsanulok $(1.02 \mathrm{mg} / 100 \mathrm{~g})$. A lower $\alpha$-tocopherol of $0.99 \pm 0.06$ $\mathrm{mg} / 100 \mathrm{~g}$ was recorded from sacha inchi nut by Souza et al. [23]. However, the current results are in line with the report of Chirinos et al. [20], who obtained $1.13-1.27 \mathrm{mg} / 100 \mathrm{~g}$ from 16 different cultivars of 
http://wjst.wu.ac.th

sacha inchi from Peru. The total tocopherol content of sacha inchi was reported to be $225.9 \mathrm{mg} / 100 \mathrm{~g}$, of which $\alpha$-tocopherol was $142.99 \mathrm{mg} / 100 \mathrm{~g}$ [17]. The differences in vitamin E content of sacha inchi from the Chiang Rai and Phitsanulok provinces and from other studies could be due to differences in variety, location, climate, farm management, harvest period, and analytical method [20].

\section{Conclusions}

The sacha inchi cultivated in both the Phitsanulok and Chiang Rai provinces was found to be characterised by excellent antioxidant activity and good fatty acids profiles. The high PUFA content of sacha inchi makes it a promising alternative to other plant-based sources. The current findings show that the highest quality sacha inchi, with the most health benefits, is found in fruits harvested when the shuck is brown and dry.

\section{Recommendations}

As nut foods usually contain a rich source of phosphorous lipids or P-containing lipids and beneficial minerals such as iron, the content of these chemical compositions in sacha inchi should be further analysed in order to provide data to industries.

\section{Acknowledgements}

The authors gratefully acknowledge the financial support of the Office of Higher Education Commission (fiscal year 2016), Thailand.

\section{References}

[1] IMD Prado, WM Giufrida, VH Alvarez, VF Cabral, S Quispe-Condori, MDA Saldana and L Cardozo. Phase equilibrium measurements of sacha inchi oil (Plukenetia volubilis) and $\mathrm{CO}_{2}$ at high pressures. J. Am. Oil Chem. Soc. 2011; 88, 1263-9.

[2] BR Hamaker, C Valles, R Gilman, RM Hardmeier, D Clark, HH Garcia, AE Gonzales, I Kohlstad, M Castro, R Valdivia, T Rodriguez and M Lescano. Amino acid and fatty acid profiles of the Inca peanut (Plukenetia volubilis L.). Cereal Chemist. 1992; 69, 461-3.

[3] Q Cai, Q Yang, SX Tang and XS Dao. Nutritional evaluation in seeds of woody oil crop Plukenetia volubilis Linneo. Acta Nutri. Sinica. 2011; 33, 193-5.

[4] D Guillén, A Ruiz, N Cabo, R Chirinos and G Pascual. Characterization of sacha inchi (Plukenetia volubilis L.) oil by FTIR spectroscopy and H-1 NMR comparison with linseed oil. J. Am. Oil Chem. Soc. $2003 ; \mathbf{8 0}, 755-62$.

[5] C Fanali, L Dugo, F Cacciola, M Beccaria, S Grasso, M Dacha, P Dugo and L Mondello. Chemical characterization of sacha inchi (Plukenetia volubilis L.) Oil. J. Agric. Food Chem. 2011; 59, 130439.

[6] BN Pietrowski, R Tahergorabi, KE Matak, JC Tou and J Jaczynski. Chemical properties of surimi sea food nutrified with omega-3 rich oils. Food Chem. 2011; 129, 912-9.

[7] C Raymer and DI Givens. N-3 fatty acid enrichment of edible tissue of poultry: A review. Lipids 2005; 40, 121-30.

[8] L Niu, J Li, M Chen and Z Xu. Determination of oil contents in sacha inchi (Plukenetia volubilis) seeds at different developmental stages by two methods: Soxhlet extraction and time-domain nuclear magnetic resonance. Ind. Crops Prdt. 2014; 56, 187-90.

[9] Q Liu, YK Xu, P Zhang, Z Na, T Tang and YX Shia. Chemical composition and oxidative evolution of Sacha Inchi (Plukentia volubilis L.) oil from Xishuangbanna (China). Grasas Aceites 2014; 65, $\mathrm{e} 012$.

[10] AOAC. Official Methods of Analysis of the AOAC International. Association of Official Analytical Chemists, Washington DC, 2000. 
http://wjst.wu.ac.th

[11] Y Shen, L Jin, P Xiao, Y Lu and J Bao. Total phenolics, flavonoids, antioxidant capacity in rice grain and their relations to grain color, size and weight. J. Cereal Sci. 2009; 49, 106-11.

[12] M Murakami, T Yamaguchi, H Takamura and T Matob. Effects of Thermal Treatment on Radicalscavenging Activity of Single and Mixed Polyphenolic Compounds. J. Food Sci. 2004; 69, 7-10.

[13] IFF Benzie and JJ Strain. Ferric reducing/antioxidant power assay: Direct measure of total antioxidant activity of biological fluids and modified version for simultaneous measurement of total antioxidant power and ascorbic acid concentration. Meth. Enzy. 1999; 299, 15-27.

[14] In-house method TE-CH-208. Central Laboratory (Thailand). Report No. TRCM60/03584, 2017, p. $1-2$.

[15] Khon Kaen AGR. J.42 Suppl. 1: 2014. An in-house Method. Central Laboratory (Thailand). Report No. TRCM60/03590. 2017, p. 1-3.

[16] L Gutiérrez, L Rosada and Á Jiménez. Chemical composition of sacha inchi (Plukenetia volubilis L.) seeds and characteristics of their lipid fraction. Grasas Aceites 2011; 62, 76-83.

[17] P Bondioli, LD Bella and P Rettke. Alpha linolenic acid rich oils. Composition of Plukenetia volubilis (Sacha inchi) oil from Perù. Rivista Italiana Delle Sostanze Grasse 2006; 83, 120-3.

[18] S Nitrayová, M Brestenský, J Heger, P Patráš, J Rafay and A Sirotkin. Amino acids and fatty acids profile of chia (salvia hispanica 1.) And flax (linum usitatissimum 1.) Seed. Sci. J. Food Ind. 2014; 8, $72-6$.

[19] ED Betancur-Hoyos, LA Urango-Marchena and LF Restrepo-Betancur. Effect of adding sacha inchi (Plukenetia volubilis L.) seeds to a prototype of convenience food draft, on the nutritional composition and sensory acceptance. J. Med. Plants Res. 2016; 10, 435-41.

[20] R Chirinos, G Zuloeta, R Pedreschi, E Mignolet, Y Larondelle and D Campos. Sacha inchi (Plukenetia volubilis): A seed source of polyunsaturated fatty acids, tocopherols, phytosterols, phenolic compounds and antioxidant capacity. Food Chem. 2013; 141, 1732-9.

[21] J Zubr. Dietary fatty acids and amino acids of camelina sativa seed. J. Food Qual. 2003; 26, 451-62.

[22] YY Shim, B Gui, PG Arnison, Y Wang and MJT Reaney. Flaxseed (linumusitatissimum 1.) bioactive compounds and peptide nomenclature: A review. Trends Food Sci. Tech. 2014; 38, 5-20.

[23] AHP Souza, AK Gohara, ÂC Rodrigues, NE Souza, JV Visentainer and M Matsushita. Sacha inchi as potential source of essential fatty acids and tocopherols: Multivariate study of nut and shell. Acta Sci. Tech. 2013; 35, 757-63. 